\title{
Measuring Community Adaptive and Transformative Capacity in the Arctic Context
}

\author{
Matthew Berman \\ Institute of Social and Economic Research \\ University of Alaska Anchorage \\ matthew.berman@uaa.alaska.edu \\ 9077865426 \\ Gary Kofinas \\ Institute of Arctic Biology and School of Natural Resources and Extension \\ University of Alaska Fairbanks \\ gary.kofinas@alaska.edu \\ 9074747078 \\ Shauna BurnSilver \\ School of Human Evolution and Social Change \\ Arizona State University \\ shauna.burnsilver@asu.edu \\ 4809658573 \\ Published as Chapter 6 in Northern Sustainabilities: Understanding and Addressing \\ Change in the Circumpolar World, Gail Fondahl and Gary N. Wilson, eds., Springer \\ International Publishing, Inc.: Cham, Switzerland, 2017, pp. 59-75.
}

\begin{abstract}
Adaptive capacity (AC) plays a prominent role in reducing community vulnerability, an essential goal for achieving sustainability. The related concept, transformative capacity (TC), describes a set of tools from the resilience paradigm for making more fundamental system changes. While the literature appears to agree generally on the meaning of AC and TC, operational definitions vary widely in empirical applications. We address measurement of AC and TC in empirical studies of community vulnerability and resilience, with special attention to the problems of arctic communities. We discuss how some challenges follow from ambiguities in the broader vulnerability model within which $\mathrm{AC}$ is embedded. Other issues are more technical, such as a confounding of stocks (capacity) with flows (time-specific inputs or outcomes). We view AC and TC as forms of capital, as distinct from flows (i.e., ecosystem services, well-being), and propose a set of sequential steps for measuring the contribution of $\mathrm{AC}$ and $\mathrm{TC}$ assets to reducing vulnerability. We demonstrate the conceptual application in a comparative analysis of $\mathrm{AC}$ in two arctic Alaska communities responding to an increase in the price of fuel. The comparative case study illustrates some key empirical challenges in measuring AC for small arctic communities.
\end{abstract}




\section{Measuring Community Adaptive and Transformative Capacity in the Arctic Context}

\section{Introduction}

Arctic communities are coping with multiple forces for rapid change, including climate warming and associated environmental effects, land-use change, fluctuating oil prices, and potential deep cuts in public spending. Because residents of arctic communities can and do move to improve well-being (Howe et al. 2013), the ability to adapt to change is a necessary condition for sustainability (Turner et al. 2003). What resources do communities have available to them to help meet the challenges of adaptation and sustainability? How can one determine which of these resources makes a difference in outcomes? Studies of community adaptation to environmental change generally group community assets for responding into one of two types. Adaptive capacity refers to assets that help communities cope with change (AC), and plays a prominent role in the vulnerability literature (Turner et al. 2003; Adger 2006; Hovelsrud and Smit 2010). Transformative capacity (TC) - a related concept in the literature on resilience of social-ecological systems (SES) - helps communities change to adapt (Kofinas et al. 2013, Wilson et al. 2013; Pike et al. 2010; Folke et al. 2009; Gallopin 2006).

Different authors in the large and growing literature on vulnerability and SES resilience generally use the same or similar sets of words when they define AC or TC. The apparent consensus dissolves, however, when they apply these terms to analyze case studies of vulnerability and resilience in communities and regions. Writers often tailor the empirical definition to their individual cases, with their unique configurations of environmental risks, historical conditions, and forces for change. Although this customization enables a rich description of the case, it greatly limits opportunities to compare cases - either over time in the same place or across different places or systems to address analytical objectives. Comparative empirical research is essential for evaluating strategies to increase $\mathrm{AC}$ and/or TC to reduce community vulnerability or increase resilience.

This chapter addresses the measurement of adaptive and transformative capacity in empirical studies of community vulnerability and resilience, with special attention to the problems facing arctic communities. We discuss how some challenges to comparing measures of community adaptive capacity follow from logical ambiguities in the broader vulnerability model within which AC is embedded. Other issues are more technical, such as a confounding of stocks (capacity) with flows (time-specific inputs or outcomes). We view AC and TC as capital stocks, distinct from flows (i.e., ecosystem services, wellbeing) (Kofinas et al. 2013). We propose a set of sequential steps for measuring the contribution of $\mathrm{AC}$ and $\mathrm{TC}$ to reducing vulnerability, and demonstrate their conceptual application in a comparative analysis of $\mathrm{AC}$ in two arctic Alaska communities responding to an increase in the price of fuel. 


\section{Adaptive Capacity and Vulnerability}

The concept of adaptive capacity is deeply embedded in the vulnerability paradigm from which it emerged. Understanding AC therefore requires a clear understanding of the vulnerability paradigm. According to a leading proponent, vulnerability describes "states of susceptibility to harm, powerlessness, and marginality of both physical and social systems ... guiding normative analysis of actions to enhance well-being through reduction of risk." (Adger 2006: 268) The definition proposed by the Intergovernmental Panel on Climate Change (IPCC) highlights the normative nature of vulnerability: "Vulnerability: the propensity or predisposition to be adversely affected." (Field et al. 2012)

Vulnerability of a social-ecological system (SES) is widely portrayed as emerging from the intersection of three essential components: exposure, sensitivity, and adaptive capacity. Exposure refers to the extent, duration and intensity of external forces of change affecting the system. Sensitivity denotes the degree to which a given exposure affects or modifies the system. Adaptive capacity (AC) is the ability of a system to accommodate change and variability without causing harm. (Adger 2006; Gallopin 2006) A SES that is highly vulnerable to climate change, for example, would be potentially sensitive to substantial harmful effects from relatively modest changes in climate, with little ability to adapt (McCarthy et al. 2001).

A large number of theoretical and empirical studies use the term vulnerability to frame problems of environmental risk in rural communities. Although authors of these studies generally associate vulnerability with exposure, sensitivity, and adaptive capacity, and use the same language to define these terms, their views of the processes that generate vulnerability often diverge (Callo-Concha and Ewert 2014; Pike et al. 2010; Gallopin 2006; Smit and Wandel 2006).

D. Callo-Concha and F. Ewert (2014) discussed a model of vulnerability in which sensitivity is the outcome that results from the interaction of exposure - an external process - with adaptive capacity -- an internal one. Their AC included feedback through a manager's perception of risk (Fig. 1). On the other hand, B. Smit and J. Wandel (2006) represented exposure, sensitivity, and adaptive capacity as a nested hierarchy of overlapping forces driven by potentially interdependent processes (Fig. 2). They consistently mentioned "exposure and sensitivity" together as a single phrase, as if the two terms were a coupled construct.

B. Turner et al. (2003) discussed the role of vulnerability analysis in sustainability science, distinguishing adaptive capacity from the capacity to cope or respond to environmental hazards - the concept that others generally call adaptive capacity. Turner et al.'s (2003) adaptive capacity enables the SES to change and potentially restructure after a disturbance. Other authors, generally those approaching SES adaptation from the resilience paradigm, call Transformative Capacity (TC) the capacity to reorganize in more fundamental ways, such as by changing key institutional arrangements (Kofinas et al. 2013, Wilson et al. 2013; Folke et al. 2009). To reduce confusion, we adopt Wilson et al.'s terminology, using AC to refer to the capacity to reduce the likelihood of harm generally, and TC to refer to the capacity for the SES to restructure more fundamentally.

Vulnerability, as it has developed in the environmental risk literature, has proved a useful concept to describe different aspects of susceptibility to harm. However, the 
widely varying interpretation of the three components - exposure, sensitivity and adaptive capacity -- and how they interact to generate that susceptibility arises from the fundamental limitations of the vulnerability paradigm as a model for grounding empirical work. Models strategically simplify reality to help illuminate how things work, demonstrate cause and effect, and predict the future: i.e., if $\mathrm{A}$ and $\mathrm{B}$ occur then $\mathrm{C}$ is a likely outcome. A good model should generate testable hypotheses; one should be able to evaluate the validity of a model by testing these hypotheses with historical data. The vulnerability model as developed in the literature falls short in three fundamental ways.

First, the model often produces no measurable outcomes (Nelson et al. 2010a). The description of vulnerability typically refers to an inferred likelihood of an imagined adverse future state, rather than to a current or historical state. No specific outcomes are defined as adverse. As Smit and Wandel (2006) put it,

"This conceptualization broadly indicates the ways in which vulnerabilities of communities are shaped. It does not necessarily imply that the elements of exposure, sensitivity and adaptive capacity can or should be measured in order to numerically compare the relative vulnerability of communities, regions or countries." (Smit and Wandel 2006: 286)

Second, the three-component vulnerability model contains contradictory logic. Specifically, it logically confounds sensitivity with adaptive capacity. A SES possessing greater AC could reduce its sensitivity to specific environmental hazards through greater preparedness and diversification. A related circularity of reasoning arises when researchers attempt to measure AC using income, harvests, or some other current SES outcome. While widespread (Nelson et al. 2010b, Adger et al. 2004, Yohe and Tol 2002, Kliskey et al. 2008, Sietchping 2007), such a practice is logically inconsistent. Since vulnerability means that adverse outcomes are likely (Field et al. 2012), using any of these outcomes to measure AC means only that bad outcomes facilitate bad outcomes.

More generally, the vulnerability model as developed in the literature confounds drivers, processes, and outcomes. For example, while exposure is typically envisioned as a purely external force for change, a number of writers have described internally generated exposures, such as demographic or economic instability, or civil conflict (Young 2009; Turner et al. 2003; Denevan 1983). The vague empirical character of vulnerability, combined with the ambiguous role of adaptive capacity, prevents the model from generating testable hypotheses. Without empirically testable hypotheses, the concepts of vulnerability and adaptive capacity remain vague generalities that are difficult to observe or refute. Measurements of AC in empirical applications emerge as idiosyncratic and ad hoc: useful for framing individual grounded case studies of communities and regions, but offering little potential for comparative research or generalization. 


\section{Measuring the role of $\mathrm{AC}$ and $\mathrm{TC}$ in vulnerability and resilience}

N. Adger (2006) emphasized the importance of consistent frameworks for measuring vulnerability that enable socially relevant quantitative and qualitative insights. G. Gallopin (2006: 302) suggested that the first step towards consistency was for researchers to agree on the definitions of "harm" and "transformation." Keeping the empirical objectives at the forefront, we begin by defining vulnerability as the probability that a specific change in an external driver (exposure) causes one or more measurable adverse outcomes to occur. The adverse outcomes would often be defined best as threshold levels for one or more measures of well-being, such as employment, income, resource harvests or nutrition. Vulnerability outcomes represent a balance between the disruptive effects of the exposure and the mitigating effects of coping activities aided by adaptive or transformative capacity. In this framework, sensitivity and vulnerability are closely related. Sensitivity refers to an incremental change in an outcome per unit change in the external driver, taking into account the effects of AC and TC. Vulnerability is the cumulative effect on the likelihood of harm.

Despite the frequent practice in the vulnerability literature of conflating resilience with negative vulnerability (Cutter et al. 2008), we follow the SES resilience literature (Kofinas et al. 2013; Walker et al 2002) and define resilience as the likelihood that the local SES maintains its key elements of structure and function after an exposure. This definition of resilience makes it a positive, not a normative concept. However, the literature on transformative capacity is normative, often placing TC as the subset of AC that promotes SES reorganization to avoid adverse outcomes (Wilson et al. 2013; Folke et al. 2009). In our view, vulnerable communities can be embedded in resilient or nonresilient SESs (Fig. 3). AC acts to mitigate the effects of exposures on activities contributing to well-being, reducing vulnerability generally (Fig. 4). TC focuses on enhancing the potential for innovative activities or new livelihoods.

The processes by which AC and TC work to reduce vulnerability can be multiscalar and complex. Households may adjust livelihood activities to maintain flows of ecosystem services, or adjust disposition of harvests through sharing relationships or organized food storage to avoid low consumption outcomes. They may also invest in infrastructure to manage environmental change, or move to a safer place (Berman 2013; Agrawal 2010). Communities may undertake collective actions such as formal redistribution, taxation and public borrowing, community moves, or public investments to harden infrastructure.

We propose, therefore, a procedure in five sequential steps, as summarized in Table 1, for the empirical analysis of the roles of AC and TC in vulnerability. The first step is to define the specific locally relevant exposure or exposures. Next, the specific indicators of vulnerability should be defined as "vulnerability of yyy to $x x x$," where $y y y$ represents the probability that a particular SES outcome yyy crosses a threshold defined as adverse, after exposure to $x x x$. Resilience, if included, would likewise be defined as "resilience of the SES to $x x x$." The third step would be to consider relevant actions that households and communities could take to try to avoid adverse outcomes, including both preventive measures and coping responses. These activities might include new activities that result from SES reorganization as well as activities that are part of the existing SES structure and function. 
Defining these activities facilitates the critical fourth step in the procedure, which is to define $\mathrm{AC}$ as the assets that help households undertake actions to avoid adverse yyy outcomes after exposure to $x x x$ and increase their effectiveness. Different authors use various names to classify the types of AC assets. Regardless of the categories used, components of AC, including its subset TC, represent drivers of vulnerability. That is, $\mathrm{AC}$ components are assets (stocks) that generate the services that directly affect vulnerability outcomes, not the services (flows) themselves. The social construction of vulnerability implies that the delineation of AC should take into account the distribution of rights (entitlements) that enable people to access these resources; unequal access to $\mathrm{AC}$ assets leads to disparate vulnerability outcomes. (Adger et al. 2003, following Sen (1981) and others).

One may use the procedure outlined in Table 1 to generate hypotheses about the effects of specific components of AC and TC on community vulnerability to various drivers of change. The hypotheses may be tested with historical data on adaptations to past exposures, or used to generate predictions of future outcomes that can be tested as the future exposures occur. To illustrate the application of the model, we consider the vulnerability of two small predominantly Alaska Native communities in northern Alaska to an increase in fuel costs. We focus on adaptive capacity within the current SES, leaving consideration of TC to future research.

\section{Comparing AC in two arctic Alaska communities}

\subsection{Setting.}

Kaktovik is a predominately Iñupiat community with about 240 residents, located on the coast of the Beaufort Sea on Alaska's North Slope. Venetie is a Gwich'in Athabascan community of about 170 people, located in northern Interior Alaska. Kaktovik and Venetie, while ethnically different, share a number of commonalities with respect to livelihoods. Households in both communities engage in a mixed economy combining subsistence resource harvests and cash incomes in household production, with social relationships facilitating flows of food and other resources among households. Cash incomes pay for motorized equipment, fuel to access resources (boats, snowmachines, all-terrain vehicles), and store-bought food. Both communities strongly articulate traditional values of sharing and cooperation (Caulfield 1983, Chance 1990, Kofinas et al. 2010, Kofinas et al., 2016) and are eligible for limited federal funding to operate tribal governments, and for Alaska Permanent Fund Dividends.

However, Kaktovik and Venetie differ with respect to a number of key elements. Table 2 summarizes some potential indicators of AC for the two communities. As a coastal community, Kaktovik has access to the marine resources of the Beaufort Sea, as well as terrestrial resources, offering it a significant benefit of ecological diversity and opportunities to harvest large marine mammals such as bowhead and beluga whales. Venetie, unlike Kaktovik, has access to wood for heating fuel.

As a North Slope community, Kaktovik benefits from its inclusion in the North Slope Borough (NSB). The ability of the NSB to tax oil infrastructure has enabled it to improve local infrastructure and public utilities in Kaktovik relative to Venetie. The median home value in Kaktovik is more than double that in Venetie, and most homes 
have piped water and sewer facilities. In Venetie only 7 percent of homes have indoor plumbing.

Most households in Kaktovik also have shareholders of the relatively wealthy Arctic Slope Regional Corporation (ASRC) and Kaktovik Iñupiat Corporation (KIC). Venetie, on the other hand, has a history of strong tribal governance that has given the community somewhat more local autonomy. A key geographic difference is one of relative remoteness. Kaktovik is one of the most remote communities in Alaska: the lowest round trip cost of air travel to the nearest urban center (Fairbanks) in April 2014 was $\$ 1,332$ per person. Venetie is much less remote, with a round-trip airfare to Fairbanks costing $\$ 320$.

\subsection{Conceptual application of 5 steps to assess vulnerability to fuel price increase.}

Clearly, many differences in AC attributes relevant to vulnerability outcomes exist for the two communities, making a true hypothesis test infeasible. Consequently, we aim to achieve a lesser goal: generate a set of testable hypotheses for vulnerability to a single exposure - an increase in fuel price - and describe how they could be tested in a future analysis.

\subsubsection{Step 1. Define specific exposure}

Between the summer of 2007 and the summer 2008, world oil prices doubled, reaching a peak of over $\$ 140$ per barrel in July 2008 , before declining sharply as the global recession set in. The effect on fuel prices in Alaska was large and immediate. The average gasoline price in Alaska rose from about $\$ 4.55$ in November 2007 to $\$ 5.97$ in October 2008. The price increase for heating oil was even greater (DCRA, 2008). Table 3 shows the effects in the two communities (DCRA 2007, DCRA 2008). Price data from the survey are not available for Venetie, so we use available information for Arctic Village, a neighboring community that shares a tribal government with Venetie and also receives all its oil and gasoline via air at comparable costs.

The prices for all fuel types in Arctic Village were much higher than in Kaktovik before the fuel increase. The North Slope Borough heavily subsidizes gasoline and provides heating oil for residential use at only the cost of delivery. Between June 2007 and October 2008, fuel prices rose substantially in both locations, although the NSB fuel subsidies substantially reduced the impact on the residential cost of heating oil in Kaktovik. However, because the gasoline price in Kaktovik started at a lower base, the relative change in prices was similar in both communities.

4.2.2. Step 2: Define locally relevant adverse outcomes.

We state a number of hypotheses for measurable outcomes.

H1: The increase in fuel costs will be associated with a larger decline in community harvest per capita (lbs), decline in food security (scale 1-10), and increase in outmigration of households in Venetie relative to Kaktovik (Table 4).

4.2.3. Step 3: Determine locally relevant actions to avoid adverse outcomes.

Households in both communities, but especially in Venetie, will be observed doing the following:

- Switching equipment for harvesting to save fuel, such as using more-efficient propeller driven boats instead of jet boats.

- Combining hunting trips with other households (e.g., leverage equipment and gas) 
- Hunting closer to the community.

- Developing systems of communication between harvest parties that increase the efficiency of hunting effort.

- Altering sharing patterns: some households may share less of a household harvest with others (e.g., store more harvest for individual use), while others may share more (e.g., share widely and decrease impact overall).

- Distributing food more widely through communal feasts.

- Households with cash from employment subsidizing those without cash for fuel.

- Using or cultivating social networks to access additional resources.

- Developing wood heat technologies (long term - Venetie only)

Village councils in both communities, but especially in Venetie, may make appeals to regulatory (e.g., Alaska Board of Game) and governing bodies (Alaska State Legislature) to liberalize harvesting regulations for more hunting season flexibility or for supplemental funding to meet resultant shortfalls.

4.2.4. Step 4: Define AC assets that increase the effectiveness of actions (see step 3) to avoid bad outcomes.

We discuss AC relevant to the specific exposure of increased fuel costs in the categories outlined in Table 2.

Ecosystems Although significantly affected by climate change, regional ecosystems remain in a healthy condition, providing important services to both communities.

Geography: Although both communities experience severe cold temperatures, Venetie's location in the boreal forest offers wood as an alternative heating source. The use of wood, however, requires equipment, some fuel, and labor.

Infrastructure (and equipment): Both communities have storage capacities for fuel and air access for delivery of fuels. Persistent higher incomes in Kaktovik derived from employment opportunities offered by the NSB may result in wider distribution than in Venetie of harvesting equipment among hunting and fishing households.

Human capital: Kaktovik's higher levels of formal education suggest that it may have more capacity to respond to an increase in fuel cost, for example, by having trained staff personnel who can help households apply for fuel cost subsidies. Both communities have skilled hunters of all ages, although rigorous measures of knowledge assets are difficult to ascertain.

Social capital: This asset includes linkages both internal (bonding networks) and external to the community (bridging networks), enhancing the ability of individuals to act collectively. Both communities show evidence of strong and active traditions of food sharing and cooperation in harvesting (Kofinas et al. 2016), which may be critical for avoiding harvest shortfalls and distributing harvests to limit food insecurity. External bonds could translate into political power through governance institutions, as discussed below. Kaktovik households on average have more food and non-food sharing ties to other households than Venetie households (Table 2), which in part reflects the additional cooperative effort involved in organizing labor and distributing meat and muktuk for bowhead and beluga whaling.

Cultural capital: One measure of cultural capital is the use and retention of Native languages (ASI 2010). Recent census data show that language retention is higher in Venetie than Kaktovik (Table 2). However, it is not clear that retention of language is 
relevant for responding to a fuel cost increase. More important is the cultural traditions of sharing and cooperative harvesting, included in the section on social capital. Both communities have broad participation in food harvesting, with similar ratios of the number of harvesters to the number of pounds harvested (Kofinas et al. 2016).

Institutional and financial capital: Venetie's tribal government owns 1.8 million acres of land outright. However the region lacks marketable resources and the tribe has no rights to tax activities on its land even if substantial economic activity did exist there. The borough status of the North Slope gives it the ability to generate extraordinary wealth from the taxation of oil and gas infrastructure. The spending of tax revenues locally provides Kaktovik and other North Slope communities with a robust cash economy that, if anything, is strengthened by the rise in oil prices. Kaktovik's association with the North Slope Borough's wealth also gives it access to subsidized gasoline and home heating fuel.

On the other hand, Venetie has pursued other opportunities to reduce fuel costs. The tribal government is actively exploring the feasibility of using wood chips to heat public buildings. For a number of years, Citgo, the U.S. subsidiary of the Venezuelan national oil company, has operated a social program that offers households a voucher to purchase 100 gallons of home heating oil annually. During the 2007-2008 fuel cost spike, Citgo contributed $\$ 5.3$ million to native non-profit organizations to purchase fuel for more than 12,000 households (USA Today 2006). Although many villages in Alaska declined to participate, Venetie was among the communities that accepted the offer. 4.2.5. Step 5: Assess contribution of AC to reducing vulnerability.

$\mathrm{AC}$ in many categories is lower in Venetie. Kaktovik's access to NSB fuel subsidies reduced the absolute change in household fuel costs there, although the percentage increase in prices was similar in both places. Although some data do exist for many of these aspects of AC, evidence supporting quantification of the effects of fuel cost increases on harvests, food security, and community population is limited. Brinkman et al. (2014) reported that increases in fuel costs over ten years reduced the number of hunting trips taken and length of trips in Venetie and seven neighboring villages. However, they also noted that households were switching equipment types to save fuel.

The population declined by 18 percent between the 2000 and 2010 censuses in both communities. However, a number of factors could be causing this trend, and it is not necessarily linked to increases in fuel prices. The federal/state heating fuel assistance program is available only for low-income residents. With a poverty rate of 14 percent, Kaktovik had far fewer households that qualified than Venetie, which had a poverty rate of 40 percent (American Community Survey 2009-2013 average), making it difficult to compare changes over time in the two communities. 


\section{Discussion}

The difficulty in documenting harm given this example of a salient and documented exposure suggests the empirical challenges to assessing contributions to vulnerability retrospectively, let alone prospectively. Community level data are rarely available at the time scale (annual) required to test the hypotheses summarized in Table 4 regarding total resource harvests, flows among households, and food insecurity .The Arctic Social Indicators (ASI) project (ASI 2014, 2010) attempted to define and measure indicators of well-being in six domains that could be used to compare communities around the Arctic. However, data for many ASI indicators -- local renewable resource harvests, for example -- are not available at the community scale on a regular basis, if at all.

The ASI case highlights the tension between generic measures of AC that may be widely available for comparative purposes versus locally relevant measures specific to the exposure and vulnerability of interest. A number of composite measures of vulnerability and/or adaptive capacity have been developed to compare a set of places with respect to common exposures (Brose 2015; Cutter 2008). However, such a prefabricated approach to assessing $\mathrm{AC}$ blends together indicators of qualitatively different assets, which typically vary in their importance locally and address different adaptation challenges. The weights that construct the aggregate index are inherently arbitrary and problematic for the varied cultural heritages and political economies of arctic communities.

The unique situation of the contribution of the North Slope Borough to AC illustrates the limitation of quantitative measures of AC for the Kaktovik-Venetie comparison. It would be difficult to find a comparable combination of institutional and financial capital available to small communities anywhere in the Arctic or even around the world. Understanding the local context of exposure and vulnerability is critical to a meaningful assessment. The best practice will always remain one that assesses adaptive capacity, qualitatively as well as quantitatively, and describes how each component and subcomponent contributes to mitigating the specific vulnerabilities analyzed.

\section{Conclusion}

While great progress has been made in the study of vulnerability, several problems remain. These include a lack of a common conceptual approach, including serious conceptual ambiguity in use of the terms exposure, sensitivity, and adaptive capacity. This conceptual ambiguity makes it difficult to compare cases, and generate and test hypotheses about adaptive capacity. The temporal dimension of vulnerability analysis (anticipated versus measured vulnerability) has often been overlooked.

In this paper we discussed those ambiguities and provided a framework to support a more systematic and reproducible empirical assessment of vulnerability, including the ability to compare cases. As an application of the framework, we worked through the case of exposure to increased fuel prices for two northern Alaska villages. We provide a brief narrative about the 2007-2008 episode of increased fuel costs to contextualize the case. Our example here is limited to describing in some detail the first 4 of the 5 steps, identifying measurable (bad) outcomes, and proposing testable hypotheses. Our data and 
analysis are clearly incomplete. However, we generate a series of outstanding questions about this approach, which motivates further discussion. 


\section{References}

Adger, W.N. (2006). Vulnerability. Global Environmental Change, 16, 268-281.

Adger, W.N., Brooks, N., Bentham, G., Agnew, M., Eriksen, S. (2004). New indicators of vulnerability and adaptive capacity. Tyndall Centre for Climate Change Research Technical Report 7, January.

Agrawal, A. (2010). Local institutions and adaptation to climate change. In Mearns, R., Norton, A. (Eds.), Social dimensions of climate change: Equity and vulnerability in a warming world (pp. 173-197). Washington, D.C.: International Bank for Reconstruction and Development (The World Bank).

ASI. (2014). Arctic Social Indicators ASI-II Implementation, Larsen, J.N., Schweitzer, P., Petrov, A. (eds). Stockholm, Nordic Council of Ministers.

http://www.svs.is/en/home/10-all-languages-content/22-the-arctic-social-indicatorsproject-asi-5.

ASI. (2010). Arctic social indicators: A follow-up to the arctic human development report. Larsen, J.N., Schweitzer, P., Fondahl, G. (Eds) Copenhagen: Nordic Council of Ministers.

Berman, M. (2013). Modeling regional dynamics of human-rangifer systems: A framework for comparative analysis. Ecology and Society, 18(4), 43. http://dx.doi.org/10.5751/ES-05535-180443.

Brinkman T, Maracle K.B., Kelly J., Vandyke M., Firmin A., Springsteen A. (2014). Impact of fuel costs on high-latitude subsistence activities. Ecology and Society. 19(4) DOI: 10.5751/ES-06861-190418

Brose, D.A. (2015). Developing a framework for measuring community resilience. Washington, DC: National Academies Press.

Callo-Concha, D., Ewert, F. (2014). Using the concepts of resilience, vulnerability and adaptability for the assessment and analysis of agricultural systems. Change and Adaptation in Socioecological Systems, 1, 1-11.

Caulfield, R. A. (1983). Subsistence land use in upper Yukon-Porcupine communities, Alaska. Juneau: Alaska Department of Fish and Game, Division of Subsistence.

Chance, N. A. (1990). The Inupiat and arctic Alaska: An ethnography of development. Fort Worth, TX: Harcourt Brace.

Cutter S.L., Barnes, L., Berry, M., Burton, C., Evans, E., Tate, E., Webb, J. (2008). A place-based model for understanding community resilience to natural disasters. Global Environmental Change, 18, 598-606.

Denevan, W.M., (1983). Adaptation, variation and cultural geography. Professional Geographer 35 (4), 399-406.

Division of Community and Regional Affairs (DCRA). (2007). Current Community Conditions: Fuel Prices Across Alaska, June 2007 Update. Alaska Department of Community and Economic Development. August.

Division of Community and Regional Affairs (DCRA). (2008). Current Community Conditions: Fuel Prices Across Alaska, November 2008 Update. Alaska Department of Community and Economic Development. December.

Field, C.B. Barros, V., Stocker, T.F., Qin, D., Dokken, D.J., Ebi, K.L., Mastrandrea, M.D., Mach, K.J., Plattner, G.-K., Allen, S.K., Tignor, M., Midgley P.M. (Eds.) (2012). Managing the Risks of Extreme Events and Disasters to Advance Climate 
Change Adaptation. Special Report of Working Groups I and II of the Intergovernmental Panel on Climate Change Cambridge, UK, and New York, USA: Cambridge University Press.

Folke, C., Chapin, F.S., Olsson, P. (2009). Transformations in ecosystem stewardship. In Chapin, F.S., Kofinas G., Folke C. (Eds.) Principles of ecosystem stewardship: Resilience-based natural resource management in a changing world (pp. 103-128). New York: Springer.

Gallopín G.C., (2006). Linkages between vulnerability, resilience, and adaptive capacity. Global Environmental Change, 16,293-303.

Hovelsrud G.K., Smit B., (Eds.) (2010). Community adaptation and vulnerability in arctic regions: Dordrecht, Springer.

Howe, E.L., Huskey, L., Berman, M. (2013). Migration in arctic Alaska: Empirical evidence of the stepping stones hypothesis. Migration Studies, doi: 10.1093/migration/mnt017.

Kliskey, A., Alessa, L., Lammers, R., Arp, C., White, D. , Hinzman, L., Busey, R. (2008). The Arctic Water Resource Vulnerability Index: an integrated assessment tool for community resilience and vulnerability with respect to freshwater. Environmental Management, 42(3), 523-541

Kofinas G., Chapin, F. S., BurnSilver, S., Schmidt, J. , Fresco, N., Kielland, K., Martin, S., Springsteen, A., Rupp, T. S. (2010). Resilience of Athabascan subsistence systems to interior Alaska's changing climate. Canadian Journal of Forest Research, 40, 1347-59.

Kofinas, G., BurnSilver. S., Magdanz, J., Stotts, R., Okada, M. (2016). Subsistence sharing networks and cooperation: Kaktovik, Wainwright, and Venetie Alaska. Fairbanks: University of Alaska Fairbanks.

Kofinas, G., Clark, D., Hovelsrud, G.K., Alessa, L., Amundsen, H., Berman, M., Berkes, F., Chapin, F.S., Forbes, B., Ford, J., Gerlach, C., Olsen, J. (2013). Adaptive and transformative capacity. In Arctic Council, Arctic resilience interim report 2013 (pp. 73-93). Stockholm: Stockholm Environment Institute and Stockholm Resilience Centre.

McCarthy, J.J., Canziani, O.F., Leary, N.A., Dokken, D.J., White, K.S. (eds.) (2001). Climate change 2001: Impacts, adaptation, and vulnerability. IPCC Third Assessment Report, Working Group II: Impacts, Adaptation and Vulnerability. Cambridge, Cambridge U. Press.

Medred, C. (2014). AK beat: Porcupine Caribou Herd hits historic highs. Alaska Dispatch, March 17.

Nelson, R., Kokic, P., Crimp, S., Meinke, H., Howden, S.M. (2010a). The vulnerability of Australian rural communities to climate variability and change: Part IConceptualising and measuring vulnerability. Environmental Science \& Policy 13 (1), 8-17. http://dx.doi.org/10.1016/j.envsci.2009.09.006

Nelson, R., Kokic, P., Crimp, S., Martin, P., Meinke, H., Howden, S.M., de Voil, P., Nidumolu, U. (2010b). The vulnerability of Australian rural communities to climate variability and change: Part II-Integrating impacts with adaptive capacity.

Environmental Science \& Policy 13 (1), 18-27. http://dx.doi.org/10.1016/j.envsci.2009.09.007 
Office of the State Assessor. (2015). Alaska taxable 2014. Anchorage: Alaska Department of Commerce, Community and Economic Development, January.

Ostrom, E. (1990). Governing the commons: The evolution of institutions for collective action. Cambridge: Cambridge University Press.

Pike, A., Dawley, S., Tomaney, J. (2010). Resilience, adaptation and adaptability. Cambridge Journal of Regions, Economy and Society, 3, 59-70. doi:10.1093/cjres/rsq001

Sen, A.K. (1981): Poverty and famines: an essay on entitlement and deprivation. Oxford: Clarendon.

Shepro, C. E., D. C. Maas, et al. (2003). North Slope Borough 2003 economic profile and census report. Barrow, Alaska, North Slope Borough, Department of Planning and Community Services.

Sietchiping, R. (2007). Applying an index of adaptive capacity to climate change in northwestern Victoria, Australia. Applied GIS 2 (3), 16.1-16.28. DOI: 10.2104/ag060016.

Simmie, J., Martin, R. (2010). The economic resilience of regions: towards an evolutionary approach. Cambridge Journal of Regions, Economy and Society, 2, 117. doi:10.1093/cjres/rsp029

Smit B., Wandel J. (2006). Adaptation, adaptive capacity and vulnerability. Global Environmental Change, 16, 282-292.

Turner II., B.L., Kasperson, R.E., Matson, P.A., McCarthy, J.J., Corell, R.W., Christensen, L., Eckley, N., Kasperson, J.X., Luers, A., Martello, M.L., Polsky, C., Pulsipher, A., Schiller, A., (2003). A framework for vulnerability analysis in sustainability science. Proceedings of the National Academy of Sciences of the United States of America, 100 (14), 8074-8079.

USA Today. (2006). Alaska villages reject Venezuela oil. http://usatoday30.usatoday.com/news/nation/2006-10-09-alaska-venezuela_x.htm.

Walker, B., Holling, C. S., Carpenter, S. R., and Kinzig, A. (2004). Resilience, adaptability and transformability in social-ecological systems. Ecology and Society, 9(2)5, http://www.ecologyandsociety.org/vol9/iss2/art5.

Wilson, S., L. J. Pearson, Y. Kashima, D. Lusher, and C. Pearson. (2013). Separating adaptive maintenance (resilience) and transformative capacity of social-ecological systems. Ecology and Society, 18(1), 22.

Yohe, G., Tol, R. (2002). Indicators for social and economic coping capacity: Moving toward a working definition of adaptive capacity. Global Environmental Change, $12,25-40$.

Young, O.R., (2009). Institutional dynamics: Resilience, vulnerability and adaptation in environmental and resource regimes. Global Environmental Change, 20, 238-385. doi:10.1016/j.gloenvcha.2009.10.001 
Table 1. Stepwise procedure for determining role of adaptive capacity (AC) in mitigating vulnerability

Step

1. Define specific exposure or exposures to analyze

2. Define locally relevant adverse outcomes that could occur from the exposure(s)

3. Determine locally relevant actions to avoid adverse outcomes

4. Define $\mathrm{AC}$ as assets that increase effectiveness of actions to avoid bad outcomes

5. Assess contribution of $\mathrm{AC}$ to reducing sensitivity (change in outcome related to wellbeing) and vulnerability (likelihood of bad outcome)

Notes Examples

External drivers of change

Typically an indicator exceeding or falling short of a defined threshold

Actions households are taking or could take

Stocks, not flows; i.e., ecosystem health rather than ecosystem services

Given the exposure pattern, is higher measured relative $\mathrm{AC}$ associated with responses that provide higher well-being?
Sea ice retreat, permafrost melt

Food insecurity, infrastructure damage

Shift harvest times or target species, harvest sharing, harden infrastructure

Knowledge systems, healthy ecosystems, effective institutions

Compare different places or same place over time, using historical data on exposure, $\mathrm{AC}$, and well-being 
Table 2. Domains and indicators of adaptive and transformative capacity: summary comparison of two arctic communities

\begin{tabular}{|c|c|c|c|c|}
\hline $\begin{array}{l}\text { Capacity } \\
\text { domain }\end{array}$ & Category & Indicator & Kaktovik & Venetie \\
\hline \multirow[t]{2}{*}{ Ecosystems } & $\begin{array}{l}\text { Ecological } \\
\text { diversity }\end{array}$ & $\begin{array}{l}\text { Main harvested } \\
\text { species }\end{array}$ & $\begin{array}{c}\text { Marine mammals, } \\
\text { caribou, Dall } \\
\text { sheep }\end{array}$ & $\begin{array}{l}\text { Salmon, } \\
\text { moose, } \\
\text { caribou }\end{array}$ \\
\hline & Ecosystem health & $\begin{array}{l}\text { Porcupine caribou } \\
\text { herd population }^{1}\end{array}$ & $\begin{array}{c}\text { 197,000 (record } \\
\text { high) }\end{array}$ & $\begin{array}{c}197,000 \\
\text { (record high) }\end{array}$ \\
\hline \multirow[t]{2}{*}{ Geography } & Climate & $\begin{array}{l}\text { Heating degree } \\
\text { days }^{2}\end{array}$ & 19,763 & 17,280 \\
\hline & Remoteness & $\begin{array}{l}\text { Round-trip airfare } \\
\text { to Fairbanks }\end{array}$ & $\begin{array}{c}\$ 1,332 \text { (April } \\
2014)\end{array}$ & $\begin{array}{l}\$ 320 \text { (April } \\
2014)\end{array}$ \\
\hline \multirow[t]{2}{*}{$\begin{array}{l}\text { Human } \\
\text { capital }\end{array}$} & Formal education & $\begin{array}{l}\text { Pct. of population } \\
25+\text { with a high } \\
\text { school degree }^{1}\end{array}$ & $74 \%$ & $47 \%$ \\
\hline & $\begin{array}{l}\text { Traditional } \\
\text { knowledge }\end{array}$ & $\begin{array}{l}\text { Number of skilled } \\
\text { hunters by age }\end{array}$ & high, all ages & high, all ages \\
\hline \multirow[t]{2}{*}{$\begin{array}{c}\text { Physical } \\
\text { infrastructure }\end{array}$} & Housing quality & $\begin{array}{l}\text { Median house } \\
\text { value }^{3}\end{array}$ & $\$ 110,400$ & $\$ 50,000$ \\
\hline & $\begin{array}{l}\text { Water-sewer } \\
\text { system }\end{array}$ & $\begin{array}{c}\text { Percentage of } \\
\text { homes with } \\
\text { plumbing facilities }\end{array}$ & $\begin{array}{l}90 \% \text { homes piped } \\
\text { water/ sewer }\end{array}$ & $\begin{array}{l}7 \% \text { homes } \\
\text { flush/haul, } \\
93 \% \text { none }^{5}\end{array}$ \\
\hline $\begin{array}{l}\text { Social } \\
\text { Capital }\end{array}$ & Social Ties & $\begin{array}{l}\text { Household degree } \\
\text { (No. of ties/HH) })^{6}\end{array}$ & 44.6 & 29.2 \\
\hline $\begin{array}{l}\text { Cultural } \\
\text { capital }\end{array}$ & $\begin{array}{l}\text { Language } \\
\text { retention }\end{array}$ & $\begin{array}{c}\text { Pct. of population } \\
5+\text { speaking Native } \\
\text { language }^{1}\end{array}$ & $41 \%$ & $68 \%$ \\
\hline Institutions & Local government & $\begin{array}{l}\text { Main local } \\
\text { authority }\end{array}$ & $\begin{array}{l}\text { North Slope } \\
\text { Borough }\end{array}$ & $\begin{array}{c}\text { Tribal } \\
\text { government }\end{array}$ \\
\hline $\begin{array}{c}\text { Financial } \\
\text { Capital }\end{array}$ & $\begin{array}{l}\text { Local revenue } \\
\text { base }\end{array}$ & $\begin{array}{l}\text { Per-capita taxable } \\
\text { property value }\end{array}$ & $\$ 2.4$ million & -- \\
\hline \multicolumn{5}{|c|}{ Medred (2014) } \\
\hline \multicolumn{5}{|c|}{ National Weather Service climate data } \\
\hline \multicolumn{5}{|c|}{ American Community Survey, 2009-2013 average. } \\
\hline \multicolumn{5}{|c|}{ Shepro et al. (2003) } \\
\hline \multicolumn{5}{|c|}{$\begin{array}{l}\text { Quarterly Report: 2015, October - December (Q2), Venetie: } \\
\text { http://commerce.alaska.gov/cra/DCRAExternal/RUBA. }\end{array}$} \\
\hline \multicolumn{5}{|c|}{$\begin{array}{l}\text { Kofinas et al. (2016). Household degree in Kaktovik includes whale feasts. } \\
\text { Office of the State Assessor (2015), } 2014 \text { appraisal data. }\end{array}$} \\
\hline
\end{tabular}




\section{Table 3. Fuel Cost Changes 2007-2008}

\begin{tabular}{|c|c|c|c|c|c|}
\hline Community & Fuel product & $\begin{array}{c}\text { June } 2007 \\
\text { price }^{\mathrm{a}} \\
\end{array}$ & $\begin{array}{c}\text { October } \\
2008 \text { price }^{b}\end{array}$ & $\begin{array}{l}\text { Absolut } \\
\text { e change }\end{array}$ & $\begin{array}{c}\text { Percentage } \\
\text { change }\end{array}$ \\
\hline \multirow[t]{3}{*}{ Kaktovik } & Heating oil, residential & $\$ 1.50$ & $\$ 2.00$ & $\$ 0.50$ & $33 \%$ \\
\hline & $\begin{array}{l}\text { Heating oil, } \\
\text { commercial }\end{array}$ & $\$ 4.95$ & $\$ 6.95$ & $\$ 2.00$ & $40 \%$ \\
\hline & Gasoline, retail & $\$ 3.45$ & $\$ 4.90$ & $\$ 1.45$ & $42 \%$ \\
\hline \multirow{2}{*}{$\begin{array}{l}\text { Arctic } \\
\text { Village }\end{array}$} & Heating oil, residential & $\$ 6.35$ & $\$ 9.00$ & $\$ 2.65$ & $42 \%$ \\
\hline & $\begin{array}{l}\text { Heating oil, } \\
\text { commercial }\end{array}$ & $\$ 6.35$ & $\$ 9.00$ & $\$ 2.65$ & $42 \%$ \\
\hline $\begin{array}{l}\text { a DCRA (2007) } \\
\text { b DCRA (2008) }\end{array}$ & Gasoline, retail & $\$ 7.00$ & $\$ 9.00$ & $\$ 2.00$ & $29 \%$ \\
\hline
\end{tabular}


Table 4 - Hypothesized measurable outcomes from increase in fuel costs

\begin{tabular}{|c|c|c|}
\hline Variable & Hypothesized outcome & $\begin{array}{l}\text { Measurable outcome- Compare } \\
\text { proportional change in: }\end{array}$ \\
\hline Harvest & $\begin{array}{l}\text { Decline in harvest at } \\
\text { community scale }\end{array}$ & $\begin{array}{l}\text { Total lbs harvested by } \\
\text { community }\end{array}$ \\
\hline $\begin{array}{l}\text { Inter-household sharing of } \\
\text { harvest }\end{array}$ & $\begin{array}{l}\text { Decline in aggregate } \\
\text { community sharing }\end{array}$ & $\begin{array}{l}\text { Total lbs of flows between } \\
\text { households, density of ties, } \\
\text { number of households receiving }\end{array}$ \\
\hline Food security & $\begin{array}{l}\text { Decline in food } \\
\text { security }\end{array}$ & $\begin{array}{l}\text { Increase in the number of } \\
\text { households reporting food } \\
\text { insecurity using USDA } \\
\text { measures }\end{array}$ \\
\hline Migration & $\begin{array}{l}\text { More out-migration. } \\
\text { Decrease in base of } \\
\text { highly productive adult } \\
\text { community residents }\end{array}$ & $\begin{array}{l}\text { Total population and } \\
\text { demographics; sufficient } \\
\text { population of youth to maintain } \\
\text { school }\end{array}$ \\
\hline $\begin{array}{l}\text { Increase in need for public } \\
\text { assistance }\end{array}$ & $\begin{array}{l}\text { Increase in applications } \\
\text { for heat subsidies }\end{array}$ & $\begin{array}{l}\text { Increase no. of applications for } \\
\text { heating program. }\end{array}$ \\
\hline
\end{tabular}


Figure 1: Ontology of vulnerability: interaction of exposure, adaptive capacity, and sensitivity, from Callo-Concha and Ewert (2014).

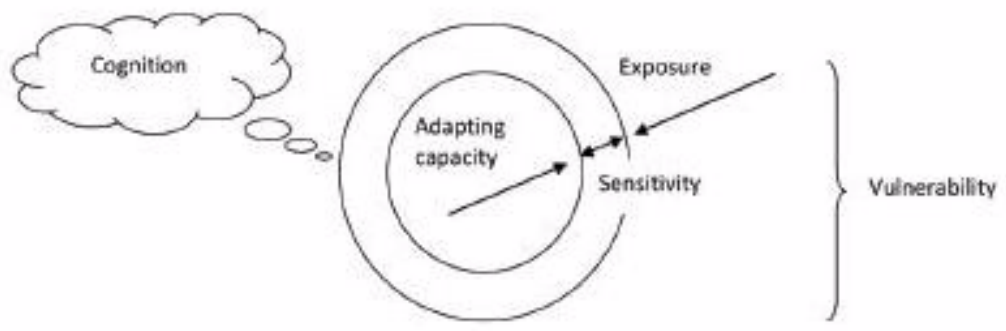


Figure 2. Nested hierarchy model of vulnerability, from Smit and Wandel (2006: 286).

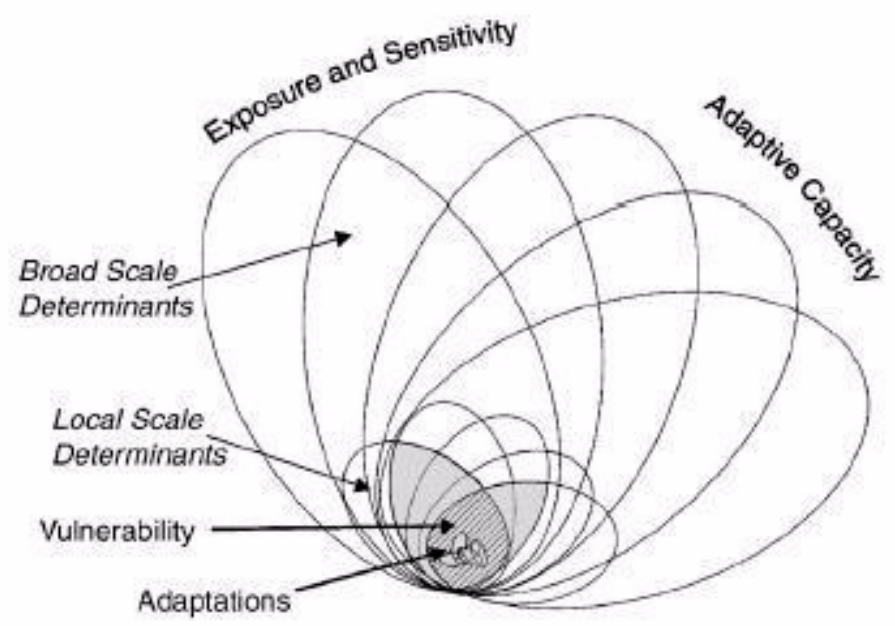


Figure 3. Characterization of social-ecological systems with respect to vulnerability and resilience.

\begin{tabular}{c|c|c|}
\multicolumn{2}{c}{ Vulnerability } \\
Resilience & High & Low \\
\hline High & Poverty trap & $\begin{array}{c}\text { Stable, high- } \\
\text { performing }\end{array}$ \\
\hline Low & Refugee risk & Opportunistic \\
\hline
\end{tabular}


Figure 4. Empirically tractable model of vulnerability and resilience

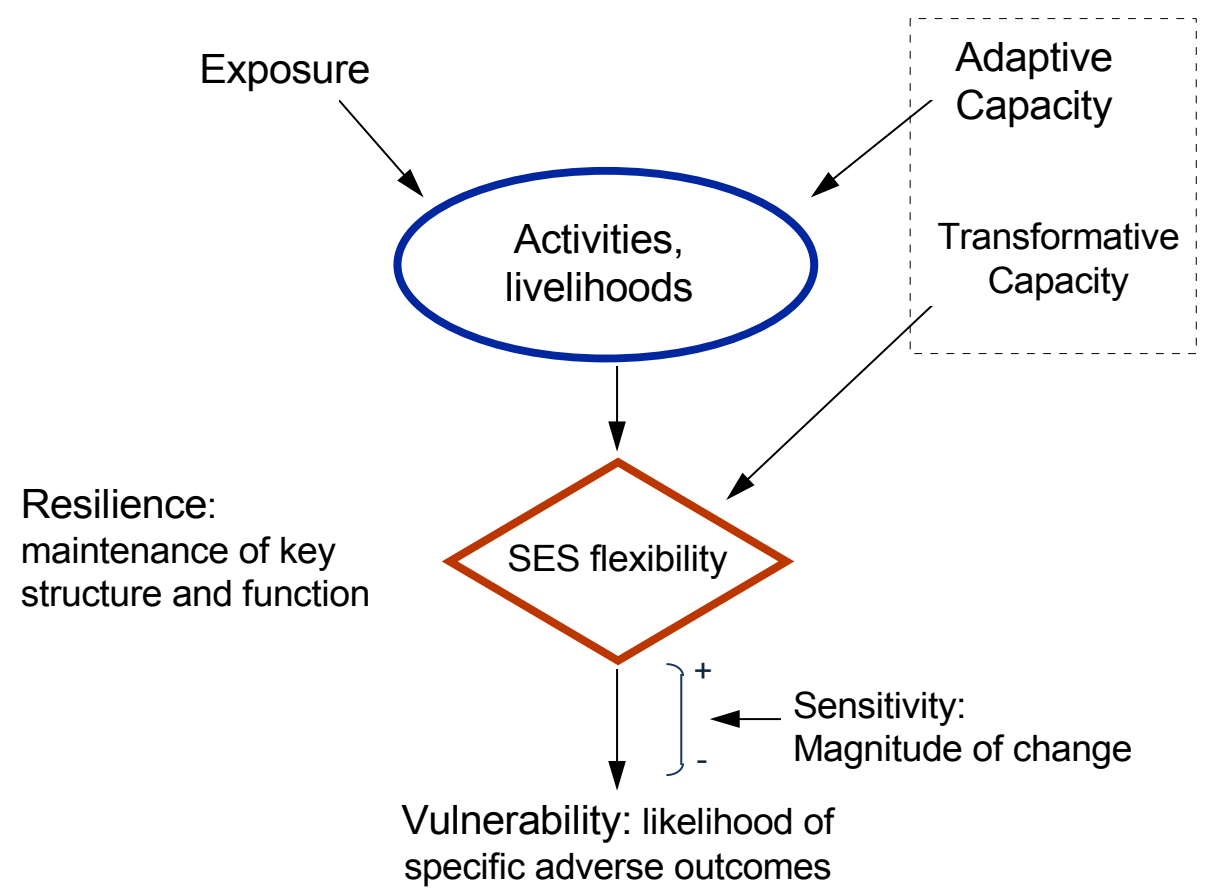




\section{Index keywords:}

Adaptive Capacity

Transformative Capacity

Vulnerability

Resilience

exposure

sensitivity

Inupiat

Gwich'in

fuel price

subsistence harvest

sharing

Kaktovik, Alaska

Venetie, Alaska

Arctic Social Indicators

North Slope Borough

Chapter keywords:

vulnerability

resilience

fuel price

Alaska 